\section{John Herz}

The following are excerpts from an address given at the CommemorativeCelebration Honoring John H. Herz The Graduate Center of the City University of New York March 15, 2006

John Herz passed away quietly at his home in Scarsdale, NY, on December 26, 2005, at the age of 97. He donated his body to the New York Medical College. His ashes will be buried near family members in Louisville, KY. It seems that everyone who hears how John died says that is the way he or she wants to go. That is an understandable reaction, but what is really to be envied is the extraordinary acuity of John's mind and memory up to the very end.

In his old age, John's eyesight and hearing were very poor. Three years ago, he wrote: "I have been unable to follow the professional literature over the last 15 years or so because of reading blindness." But he absorbed the New York Times and other reading matter through the use of a magnifying machine and the occasional help of readers. He could still carry on a conversation with one person, although conversation in a group was difficult and one could tell by his expression that he was lost. One day at lunch, my wife Mary and I talked with a young waitress from Poland who was a student. When she left, John asked: is she pretty? Yes, I said. His verbatim response was "What I miss is seeing beautiful women and hearing beautiful music." Not only did he know much about music and the political significance of operatic plots; sometimes he would even make a stab at singing an operatic melody.

For his age, John was in excellent health and was looking forward to visiting his sister and brother-in-law in California later this year. I was continually amazed at how agile he was, going up and down the stairs like a gazelle. Of course, he was slowing down. In the last few years, John would sometimes say: I have lived too long; it is time to go. But he was intellectually too busy to go. He contributed to a book that was published just after his death: Global Survival: The Challenge and Its Implications for Thinking and Acting, edited by Ervin Laszlo and Peter Seidel. And he wrote the introduction to a forthcoming book, which I shall describe shortly.

A German graduate student, Jana Puglierin, has been writing her dissertation on John Herz. She had come to the United States to interview him, and he was busy answering her follow-up ques- tions by mail. I shall read part of a letter from Jana:

Although we had exchanged a number of letters prior to meeting in person, I was utterly unprepared for our first encounter. We met daily for a week, and during all those meetings, he did not leave one of my questions unanswered. His answers were thorough and comprehensive; he effortlessly explained the thinking behind his theories and passionately commented upon the political events of the day. Whereas, from time to time, I would suggest taking a break, he never tired, always willing to continue our discussions, to keep on working, as he said.... He steadily encouraged me to pepper him with questions and to put his theories to the test in my dissertation. In contrast to many a scientist, John never considered dissenting opinions a threat, but a welcome challenge.... His letters were rich in suggestions, remarks on the topics of our discussion and anecdotes about his life.

Despite the tribulations of age, John's concern about vital public issues was as keen as ever to the end. Occasionally, on the telephone he would say, I feel quite depressed today. I knew he was not referring to some annoyance or a physical affliction. He was depressed because, in the New York Times, he had read about another violation of international law, misconceptions about the crime of terror as a war, a failure to support family planning and population control, some ignorant comment about global warming, the growing destruction of the human habitat, unconcern about nuclear proliferation, some new evidence of disaster in the war in Iraq, or another lost opportunity to raise the minimum wage.

John was born in Dusseldorf, Germany in 1908, after the beginning of a century that he was to call a century of missed opportunities. His was a secular Jewish-German family. His father was a federal judge, and John studied law as well as political science, earning his doctorate at the University of Cologne before Hitler came to power. After the Nazi takeover, John moved to Geneva, where he studied at the Graduate Institute of International Studies. He published his first book, in German, on The Nationalist Socialist Doctrine of International Law, warning about the aims of the Nazis. Because his parents and young sister had not yet been able to leave Germany, he wrote under a pseudonym.

When World War II broke out, he was at the beginning of two stimulating years at the Princeton Institute for Advanced Studies, where he heard Albert Einstein play the violin, badly. Before Pearl Harbor, in 1941, John was hired by Ralph Bunche at Howard University, in the racially segregated city of Washington, D.C. John was among a number of Jewish refugee scholars who were able to find teaching positions in black colleges and universities. His experience was the impetus for a documentary film, From Swastika to Jim Crow. He and his wife, Anne, are interviewed extensively in this film.

During World War II, John worked as a political analyst for the Office of Strategic Services (OSS). For three years after the war, he was an analyst in the State Department, working mainly on the reconstruction of German democracy. One of his memorable experiences was working for the U.S. War Crimes Prosecutor at the Nuremburg Trial.

Unlike some refugees who could not bear to return to Germany, John visited after the war, continuing to play a role in the reconstruction of democracy and the revival of political science. Thirty years after the end of the war, I attended a large assembly at the German Consulate in New York, where John received the Order of Merit of the Federal Republic from the president of Germany.

While at Howard, John conceived the concept and coined the term "security dilemma," which first appeared in an article in World Politics in 1950 and was to be perhaps his most influential concept. Last year, he wrote: "Since the beginning of history and despite all the achievements of civilization, we continue to ask: why wars? Why have we been slaughtering each other on end? Scientific answers have been offered only since the early decades of the twentieth century .... The international system was seen as an anarchic system, in which sovereign nation-states must rely on themselves for protection by others. But even peace-minded states and their decision-makers, so I thought, might create in others the fear that they were preparing for armed attack and possible conquest. So they, in turn, increase their power, and there emerges a vicious circle of power competition and armament races, leading eventually to war."

An editor of the aforementioned forthcoming book is Kenneth Booth, the E. H. Carr Professor at the University of Wales. His department, founded in 1919, was the first to be devoted to international politics and is one of the largest in Europe. I am pleased to be able to quote from his remarkable letter:

John Herz was part of my life for 40 years, though I never met him. I first came across his name when I was a student in the 1960s. I read a number of his 
books and articles, and immediately felt that Herz's work spoke to me in a way most other academic authors did not.... Only in 2003 did I discover he was still alive, by which time I was writing a book on one of Herz's significant contributions to the literature: the concept of the security dilemma. I treasure the letters and contact we had in these last years of his life. As a result of this contact, I was able (as editor of the journal International Relations) to publish what I think was John's final academic article. This article received more hits (downloads) than any other in the journal that year. When our book (which is entitled The Security Dilemma: Fear, Cooperation, and Trust in World Politics) finally began to make serious progress, we asked John if he would write the foreword. This he readily agreed to do, and he finished it on 26 November, exactly one month before he died.... I will always regret we did not meet, but I am happy on this sad occasion that John knew we were dedicating the book to him; that he knew like-minded scholars were developing his heritage; that he understood how we were putting the security dilemma at the heart of the theory and practice of International Relations; and that he had the opportunity to glimpse, in a preliminary form, our argument that in this new age of uncertainty, the concept he invented 50 years ago is an idea whose time has truly come.

In 1951, the year before John came to City College, his first book in English won the annual Woodrow Wilson prize of the American Political Science Association. Entitled Political Realism and Political Idealism, it was reprinted twice and also published in German. The following year, he became co-author with Gwendolen Carter of a comparative government textbook, The Major Foreign Powers, writing the section on Germany. The book was written with such lucidity that it became one of the most widely used texts in the country. John updated the section on Germany four times in 20 years.

With a recommendation from Ralph Bunche, John joined City College in 1952. He taught for 27 years, until 1979, and also, of course, at the Graduate School. John also taught at the Free University of Berlin, Marburg University, the Fletcher School of Law and Diplomacy, Columbia University, the New School for Social Research, and elsewhere.

A grant from the Rockefeller Foundation in the late 1950s gave John a year off from teaching and the opportunity to write one of his best-known books, International Politics in the Atomic Age. It was reprinted eight times, six times in paperback. One of my favorite passages in the literature of political science is a paragraph from the introduction to this book.

This is an old-fashioned kind of book. It is the result neither of teamwork nor of any similar type of group study or collective research. It is not the product of a seminar, nor that of a study conference for which the author served as reporter. It has not been issued from a lecture series, and it is not based on a field trip or any wide traveling whatsoever. The author has not used a single IBM facility in the book's preparation, nor has he conducted any interviews for it, whether in depth or otherwise. There has not been any polling, nor have questionnaires been distributed. As a matter of fact, the book does not contain a single chart, graph, map, diagram, table, or statistical figure. It is simply the product of the application to problems and subject matter at hand of whatever intelligence was available.

A spin-off from The Major Foreign Powers was Government and Politics in the Twentieth Century, also co-authored with Gwendolen Carter. It appeared in eight languages. In the late 1970s, 12 of John's essays were published in The Nation-State and the Crisis of World Politics. In the early 1980s, he edited a volume entitled From Dictatorship to Democracy: Coping with the Legacies of Authoritarianism and Totalitarianism. And in the 1980s his intellectual autobiography appeared in German, On Survival: The Development of My World View. An English translation of the first seven chapters is available in typescript.

John was prolific in writing articles and book reviews. His papers are at the State University of New York at Albany in a unique archive, the German and Jewish Intellectual Emigre Collection, overseen by John Spalek.

John was obsessed by his belief that, for the first time in human history, the future of every one of us is in jeopardy. From the mid-1980s, he proposed the establishment of a new political science sub-discipline-Survival Researchwhich would bring together a full array of interdisciplinary expertise. John himself financed a conference at the Graduate Center in 1988 to explore his proposal.

For over half a century, John was involved in debates about political realism. He was in much agreement with his friend and colleague Hans Morgenthau (who had emigrated to the U.S. the same year as John), but was also critical. In a debate in Los Angeles in 1980, he pointed out that Morgenthau had not seen certain developments [referring, among others, to over-population, the environment, and the depletion of resources] that were putting the very survival of the human race in jeopardy.

John renewed this criticism about a quarter-century later, in 2004, in a letter to a conference in Munich on Morgenthau and the future of realism. An organizer of the conference, Christian Hacke, believed that in the 20th century, modernized yet classical realism reached new strength on the coattails of such brilliant minds as Max Weber, E. H. Carr, Hans Morgenthau, John Herz, George Kennan, and Henry Kissinger. John was certain that Morgenthau would have denied an American national interest in the case of Iraq as he had in the case of Vietnam; and he criticized those, including Condoleeza Rice, who claimed Morgenthau as her intellectual inspiration and who, he believed, were wrong in seeing Morgenthau as an adherent of non-moral realism. John concluded that "we must have a radical change in attitudes and policies regarding collective measures taken collectively by nations cooperating through international organizations and institutions."

After declaring that radical changes were necessary, John asked himself: "Have I landed in an idealistic utopianism?" He then reached a doomsday prediction in his concluding passage: "I am afraid [that] the present United States regime will have four more years not merely to neglect the great environmental problems but actively act against what has to be done. If so, the end appears inevitable. Exeunt omnes. Finis." But he never gave up, adding that under more enlightened leadership, there may still be hope. He was a realist but not a defeatist. He was also a visionary and an inspiration to us all.

\section{Thomas G. Karis City University of New York}

\section{Ross M. Lence}

On July 11, 2006, our distinguished colleague Ross M. Lence passed away. Ross had been diagnosed with pancreatic cancer in August of 2005, and even in his most difficult moments this last year, he continued to grace our lives with his good cheer and to engage in that activity he most loved, teaching.

Ross came to the University of Houston in 1971, after completing a B.A. at the University of Chicago, graduate 